\title{
CUSTOM, NORMATIVE PRACTICE, AND THE LAW
}

\author{
GERALD J. POSTEMA $\dagger$
}

\begin{abstract}
Legally binding custom is conventionally analyzed in terms of two independent elements: regularities of behavior (usus) and convictions of actors engaging in the behavior that it is legally required (opinio juris). This additive conception of custom is deeply flawed. This Essay argues that we must abandon the additive conception and replace it with an account of custom that understands legally relevant customs as norms that arise from discursive normative practices embedded in rich contexts of social interaction characterized by intermeshing anticipations and interconnected conduct. The hallmark of legally binding customs, it is argued, is not the addition of belief or conviction to behavior, but rather the integration of meaningful conduct into a web of legally recognized reasons and arguments.
\end{abstract}

\section{TABLE OF CONTENTS}

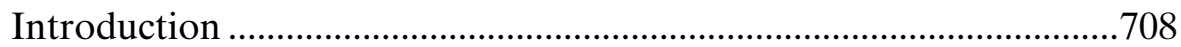

I. The Additive Conception of Custom ........................................709

II. Against Addition ........................................................................714

III. Integration, Not Addition: A Normative Practice Analysis

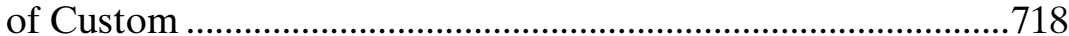

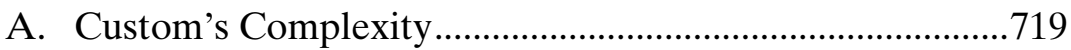

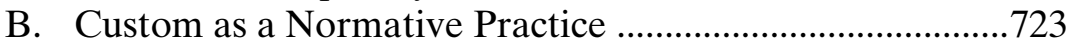

C. Discursive Normative Practices...........................................729

IV. Customary Law...........................................................................731

A. What Makes Custom Law? The Generic Question ...........732

B. What Makes a Custom a Law? The Specific Question.....735

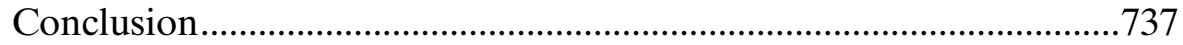

Copyright $(\odot) 2012$ by Gerald J. Postema.

$\dagger$ Cary C. Boshamer Professor of Philosophy and Professor of Law, University of North Carolina at Chapel Hill. 


\section{INTRODUCTION}

Customs, social rules, and conventions are pervasive in our lives. They guide our actions as we navigate complex interactions of social life; they give social significance to the material things that often mediate those relations; and, even more, they define horizons within which actions we conceive and deliberatively entertain actions we undertake. Moreover, for millennia custom has been regarded as an important kind, or source, or ground of law. Although its importance has seemed to decline in modern legal systems, it is often not far below the surface in important parts of municipal law, and it is still thought to play an indispensable role in international law.

An analysis that breaks custom into an external elementregularities of behavior (usus) — and an internal element-convictions of custom followers that behavior conforming to the regularities is legally required (opinio juris) - has been nearly irresistible to theorists of law and of custom generally. What is more natural than to think that custom is a matter of consistent patterns of behavior observable from the outside plus some interior state like belief, attitude, or conviction, which turns patterns of behavior into norms for behavior? Yet, this additive conception of custom, despite its dominance, is deeply flawed, if not incoherent. Many of its problems are frequently rehearsed and recognized, and then almost immediately ignored. The jurisprudence of custom has long been in the grip of a kind of additive addiction, fed by the irresistible naturalness of its approach and the absence of any plausible alternative.

The project of this Essay is to sketch such an alternative, an integrated account that proposes to understand legally relevant customs as embedded in and arising from discursive normative practices. Inspiring this alternative approach is a brief sketch of custom by an ancient sophist turned stoic, which provides a useful foil for a terse characterization of the additive conception. (It also provides evidence that the additive conception is not completely irresistible.) I then seek to break the addiction to this conception in three steps. First, I briefly show how the "outside" versus "inside" trope that dominates thinking about custom beguiles theorists into an uncritical adoption of the additive conception. Second, I argue that this conception is bedeviled by problems deeper than the paradoxes and uncertainties widely, if uncomfortably, acknowledged in the jurisprudence of custom. Finally, I articulate and defend an 
alternative conception, the normative practice account. For this purpose, I focus on three core concepts and the interrelationships between them: normative practice, reciprocally oriented conduct, and discursive interaction. The proposal is that legally significant customs take shape in discursive normative practices in rich contexts of social interaction characterized by intermeshing anticipations and interconnected conduct. I conclude with a brief discussion of the appropriateness of this conception of custom for law, especially international law. First, I argue that international relations are characterized by the kind of social interaction that provides a natural habitat for the essentially discursive practice of international law. But, second, I concede that the additive conception may still play a role in some legal systems, not as a basis for understanding the nature of custom or its normative force, but rather as framing evidentiary standards adopted by those systems for proof of the legal standing or validity of a given custom in them.

\section{The AdDitive CONCEPTION OF CUSTOM}

In his discourse on custom, Dio Chrysostom ${ }^{1}$ wrote,

Custom is a judgement common to those who use it, an unwritten law of tribe or city, a voluntary principle of justice, acceptable to all alike with reference to the same matters, an invention made, not by any human being, but rather by life and time. Therefore, while of the laws in general each obtains its power through having been approved once and for all, custom is constantly being subjected to scrutiny. Moreover, while no law will readily be chosen by everybody-for it is by the opinions of the majority that it is ratified-yet a custom could not come into being if not accepted by all. Again, while law by threats and violence maintains its mastery, it is only when we are persuaded by our customs that we deem them excellent and advantageous. ${ }^{2}$

1. Dio Cocceianus Chrysostomus was a first-century Greek orator and historian. Born in Bythinia around $40 \mathrm{CE}$, he began his career as a sophist but later embraced stoicism. Nearly eighty of his discourses or orations on a wide variety of topics survive, among them one on law (number 75) and one on custom (number 76).

2. Dio Chrysostom, The Seventy-Sixth Discourse: On Custom, in 5 Discourses 253 , 253 (T.E. Page, E. Capps, W.H.D. Rouse, L.A. Post \& E.H. Warmington eds., H. Lamar Crosby trans., 1951) (n.d.). 
Custom, Julian instructs us, is "law established by usage" customary law arises from the acts and deeds of ordinary practice. ${ }^{4}$ We can use Dio's discussion in the above passage to clarify this point: custom is a matter of judgment - that is, a matter of usage or practice involving and engaging judgment — and this custom-shaping judgment is common among participants in the practice. Although unwritten, custom has the nature and force of law. Its existence, like that of all law, is a contingent matter, being a product of invention; however, custom is made not by individual human hands and wills, but by life and time. As such it is flexible, open to reformulation and reformation, and inviting rather than silencing scrutiny. Dio highlights its voluntary character: it is approved by those it governs, approval not extracted by force or duress like enacted law, but based on persuasion and critical scrutiny. A little later he adds, with rhetorical flourish, that enacted laws "create a polity of slaves," whereas "customs, on the contrary, create a polity of free men." from the common life of the people, from their judgment-engaged practice, unlike enacted law, which is typically imposed. Their consensus is not a matter of individual agreement with the rules, but common or collective agreement in them, and therein, according to Dio, lies their claim to legitimacy.

This profile of law-determining custom stands in sharp contrast with the conception of custom dominant in modern jurisprudence. On this account, custom determines law just when added to certain regularities of behavior (usus) are facts about the attitudes, beliefs, intentions, or wills (opinio juris) of those who exhibit that behavior. ${ }^{6}$ The former is said to be the quantitative, objective, or material element of custom; the latter is said to be the qualitative, subjective, or psychological element. The International Court of Justice, writing in 1985, embraced this additive view of the juridical nature of international custom. It is "axiomatic" in international jurisprudence,

3. Alan Watson, The Evolution of LaW 44-45 (1985) (quoting Dig. 1.3.32.1 (Julian, Digest 84)).

4. See id. ("F]or Julian it appears to be that the custom is law because the people accept it as law.").

5. Chrysostom, supra note 2, at 255.

6. See, e.g., Brigitte Stern, Custom at the Heart of International Law, 11 DuKE J. COMP. \& INT'L L. 89, 91 (2011) (identifying two views of custom: "[o]n the one hand, it is a 'general practice accepted as law,' that is to say according to the most classic analysis, a material element and a psychological element, opinio juris sive necessitatis, and on the other hand, it is a norm" (footnote omitted)). 
the court in that case maintained, that customary law is to be found "primarily in the practice and opinio juris of States." This analysis has not been limited to the jurisprudence of international law, but has been used to explain customary law of all kinds. At least since the nineteenth century, this pattern of analysis has been dominant. By mid-twentieth century, it had become a commonplace as an accepted, indispensable, albeit admittedly puzzling, starting point. Professor Hans Kelsen, for example, writes,

Custom is a usual or habitual course of action, a long-established practice .... But the frequency of conduct, the fact that certain actions or abstentions have repeatedly been performed during a certain period of time, is only one element of the law-creating fact called custom. The second element is the fact that the individuals whose conduct constitutes the custom must be convinced that they fulfill, by their actions or abstentions, a duty, or that they exercise a right. They must believe that they apply a norm, but they need not believe that it is a legal norm which they apply.

In one of the most recent book-length studies of legal custom, Professor David Bederman writes,

the best algorithm for the creation of customary norms is the traditional notion that there must be both proof of an objective practice within a relevant community and a subjective determination of the value of the norm, whether expressed as a sense of legal obligation or the reasonableness of the rule. ${ }^{9}$

This formulation is notable for the almost studied ambiguity of the term "subjective," which could be taken to mean either evaluative or a matter of belief or attitude.

Professor John Tasioulas disambiguates this thesis in one way. A custom has legally binding status, in his view, when

[t]he creation of an international legal rule according to which the specified pattern of behavior would be lawful is ethically justified, and such a legal rule should be created by means of a process that

7. Continental Shelf (Libya/Malta), 1985 I.C.J. 13, para. 27 (June 3).

8. Hans Kelsen, PRINCIPLES OF INTERNATIONAL LAW 307 (1952).

9. DAVID J. BEDERMAN, CUSTOM AS A SOURCE OF LAW, at xi, 171-72 (2010). 
involves general state practice consistent with it and an ethical endorsement by states of its establishment. ${ }^{10}$

For Professor Tasioulas the ethical justification of the rule is the pivot; state practice is not even necessary. ${ }^{11}$ Professor Brian Lepard chooses the other solution to the ambiguity. Taking "opinio" literally to mean "opinion," he understands the subjective dimension in terms of parties' belief in the moral desirability of a rule of a certain sort's being recognized as law. He states his central thesis clearly at the opening of his study:

A customary international norm arises when states generally believe that it is desirable now or in the near future to have an authoritative legal principle or rule prescribing, permitting, or prohibiting certain conduct. This belief constitutes opinio juris, and it is sufficient to create a customary law norm. It is not necessary in every case to satisfy a separate "consistent state practice" requirement. Rather, state practice can serve as one source of evidence that states believe that a particular authoritative legal principle or rule is desirable now or in the near future. ${ }^{12}$

What is remarkable, although not unique, in both of these accounts is that they embrace the additive conception, accepting its dualist analytical distinction, but assign to the so-called material dimension a marginal status. That is, they rely on the dualist conceptual framework and its sharp distinction between internal, or subjective, and external, or objective, elements, but then suppress the second term of the dualism. In Professor Lepard's account, for example, state practice is regarded as only providing some evidence of the requisite state opinio juris. ${ }^{13}$ Thus these recent proposals do not reject the additive conception, but rather embrace one-sided versions of it.

10. John Tasioulas, Customary International Law and the Quest for Global Justice, in THE NAture of Customary Law: Legal, Historical And Philosophical Perspectives 307, 323 (Amanda Perreau-Saussine \& James Bernard Murphy eds., 2007).

11. Id. at 310 .

12. Brian D. Lepard, Customary International LAW: A NeW THEORy With PRACTICAL APPLICATIONS 8 (2010).

13. Id. at 122-39. Ironically, in Professor Lepard's account it turns out that the subjective side is entirely fictional. Whereas his theory takes opinio juris as the only determinant of the content and legal status of international customary norms, his practical proposal pays attention only to deeds and words. He claims that the deeds and words of states' officials must be taken as evidence of the required attitudes, but he offers no account of the evidential relationship between official deeds or words and the beliefs of states. Opinio juris, in fact, functions as a legal fiction. 
Professor Maurice Mendelson, however, suggests a very different analysis, which resists the additive conception. "A rule of customary international law," he writes, "is one which emerges from, and is sustained by, the constant and uniform practice of States and other subjects of international law, in their international relations, in circumstances which give rise to a legitimate expectation of similar conduct in the future." ${ }^{14}$ A similar analysis can be found in the Uniform Commercial Code (in a section authored by Professor Karl Llewellyn). It defines a legally binding "usage of trade" as "any practice or method of dealing having such regularity of observance in a place, vocation, or trade as to justify an expectation that it will be observed with respect to the transaction in question." ${ }^{15}$ On this view, rather than isolating and combining two distinct components-usus and opinio juris - the practice of participants in the custom is set in a context of interaction from which legitimate expectations arise.

Mendelson, Llewellyn, and Dio Chrysostom are rare among analysts of legal custom. Most legal theorists, beguiled by the outside/inside trope, have found the additive conception nearly irresistible. This trope leads those who observe the outside of customary conduct to search for something on the inside to explain its legal status, and the only eligible sense of "inside" seemed to be "internal," or "mental." Often background theoretical commitments reinforce this natural move. In international-law theory, for example, when the doctrine of state sovereignty was dominant, it was thought that respect for the sovereign equality of states entailed that states could be bound only by consent. Consent was thought to be explicit in treaty regimes and implicit in customary law, although no less important because implicit. Consent was a matter of some internal attitude of the officials of states. ${ }^{16}$

Theorists have also been beguiled by this trope when they thought of custom as a source of law. On a dominant view, sources of law are thought of in terms of origins in a canonical kind of event, namely, behavior manifesting an exercise of will. ${ }^{17}$ To think of custom

14. Maurice H. Mendelson, The Formation of Customary International Law, 272 RECUEIL DES COURS 155, 188 (1998) (emphasis omitted).

15. U.C.C. $\S 1-303(c)(2012)$.

16. Raphael M. Walden, former Director of the Treaty Division in the Israeli Ministry of Foreign Affairs, offers a thorough discussion of this trend in Raphael M. Walden, The Subjective Element in the Formation of Customary International Law, 12 ISR. L. REV. 344 (1977).

17. This view has its roots in classical positivist legal theory. See generally, e.g., JOHN Austin, THE PROVINCE OF JURISPRUDENCE DETERMINED (1832). For a general discussion of 
as a source of law, on this view, is just to think of it as a mode of lawmaking on the model of explicit legislation involving an exercise of will. Francisco Suárez's thoughts about custom in law illustrate this beguiled line of thought. ${ }^{18}$ Initially, he distinguished two dimensions of custom: its factual dimension and its juridical dimension. ${ }^{19}$ But when he turned to an analysis of the juridical dimension, his general theory of law dictated his analysis of custom. Custom, he argued, is made by the people..$^{20}$ But, because all law, on Suárez's view, is the product of will and intention, he inferred that custom has juridical status only if it proceeds from the will and intention of the people, the relevant intention being an intention to establish the rule as legally binding. ${ }^{21}$ This conclusion suggests the additive conception of custom, to which Suárez was led by his general jurisprudential commitments.

We must follow the lead of Dio Chrysostom and Professor Mendelson and resist these beguilements, because the additive analysis of custom to which they lead is untenable.

\section{AgAinst AdDition}

The additive conception regards legally binding customary practice as the combination of two discrete sets of empirical facts: facts about behavior and facts about attitudes (beliefs, feelings, desires, approvings, intendings, and the like). Regularities of behavior, thought to be observable and recognizable apart from considering the attitudes (that is, viewed from the outside), are said to be transformed when those who engage in those regularities have the right kind of attitude or mental state, namely, regarding themselves as

this trend in legal theory, see Gerald J. Postema, Legal Positivism-Early Foundations, in THE Routledge Companion to Philosophy of LAW 31 (Andrei Marmor ed., 2012), and references therein.

18. Francisco Suárez (1548-1617), philosopher, theologian, and legal theorist, was a leading figure in the Second Scholastic School of Salamanca. He wrote extensively on topics in metaphysics and general philosophy, but his work, A Treatise on Laws and God the Lawgiver (1612), is a major contribution to legal philosophy and is among the two or three most important early theories of international law.

19. Francisco SuÁrez, A Treatise on Laws and God the Lawgiver, in 2 SElections From THREE WORKS OF FrAncisco SuÁREZ, S.J. 440, 447-48 (James Brown Scott ed., Gwladys L. Williams, Ammi Brown, John Waldron \& Henry Davis trans., 1944) (1612).

20. Id. at 553 .

21. Id. at 565. I mistakenly overlooked this part of Suárez's account of custom in Gerald J. Postema, Custom in International Law: A Normative Practice Account, in THE NATURE OF CUSTOMARY LAW, supra note 10, at 279-80, 287. 
bound by the rule constituted by that behavioral regularity, or approving of that rule, or some other similar attitude.

Consider, first, the behavioral dimension. It is true that a custom does not exist unless it is instantiated in the behavior of people allegedly governed by it. But, strictly speaking, there is no such thing as the custom's rule-the regularity of behavior-viewed on its own. It is a commonplace view of contemporary philosophy that the problem is not that no rule or pattern can be constructed from a collection of bits of behavior, but rather that an indefinite number of such patterns are logically projectable from the same collection. But if there is an indefinite number of such projectable patterns, then there is no rule. For a rule is a discrete pattern with some claim to normative status for those engaged in the practice that distinguishes behavior in accord with it from other modes of behaving, treating them as wrong, or mistaken, or violations. No pattern that exists simply as one among an indefinite number can make that claim. Projectable patterns are not (yet) rules. Of course, not all possible projectable patterns are salient to us; indeed, only a few will be. And it may be that what is salient to one of us is salient to many of us; we might as a matter of fact see the same pattern. But there is no reason to be confident that this convergence identifies the custom-relevant pattern in the bits of behavior that are available to observers. The custom-relevant pattern is the pattern made meaningful by the practice, not some other pattern that many inside or outside the practice can identify. Indeed, the pattern is likely to be salient because it is meaningful within the practice, rather than meaningful because it is salient.

Thus, instances of behavior exhibit a custom-relevant regularity only when viewed as deeds - that is, as socially meaningful. And we can uncover this meaning only from within the practice. Should we say, then, that we can uncover this meaning only, as Professor H.L.A. Hart put it, "from the internal point of view"? 22 There is something right about this suggestion, but it is misleading if we adopt a reading of "internal point of view" that many have found tempting. That is, it is tempting to regard the internal point of view that Professor Hart talks about as the domain of the attitudes of participants in the practice. And that way of understanding the internal point of view seems to return us to the additive conception. On this reading, we might say that the relevant convergence of behavior just is the

22. See H.L.A. HART, THE CONCEPT OF LAW 88-91, 102-03 (2d ed. 1994). 
regularity that is isolated in the content of the convergent attitudes of these participants - in other words, the behavior is convergent only when participants have the same rule in mind and take the same relevant attitudes toward it. This proposal, however, also fails to understand the nature of normative practices.

One reason for its failure lies in the fact that customs are social rules, not mere personal resolutions. Thus, the relevant convergence of attitudes must not be accidental. The mere fact that a number of people regard a certain kind of behavior as required of them and that they happen to have the same kind of behavior in mind does not guarantee that they are practicing or following a common rule. What, then, must we add to this convergence to make sure that we have a common rule in view? Professor Hart suggested two different conditions. One qualified the content of the rule on which there was convergence: each must view the regularity as a common, public standard, as opposed to seeing it as just a rule for me, a rule that I act on "for [my] part only." "23 The other condition qualified the agents' reason for complying: each must follow the rule in part for the reason that it is widely followed by others. ${ }^{24}$

Professor Hart's suggestions have provoked much thinking about custom and social rules in recent years, but neither of them guarantees that a convergence of behavior or attitude explained in these ways, should it occur, is not merely accidental. The latter suggestion puts convergence of the behavior among the conditions of complying with the rule, but it does not guarantee nonaccidental convergence of the content of attitudes regarding the rule. The former suggestion brings into view a more fundamental problem facing this way of fixing the rule of the practice. Talk of convergence of the content of internal attitudes presupposes that it is possible to determine that participants have the same rule in mind without appeal to regularities of behavior viewed from the outside.

This determination cannot be done, however. The content of the rule that any one agent seeks to follow gets determinate content only insofar as it fits into two other aspects of the practice to which the agent's conduct contributes: the network of reasons and the network of accountability given shape by the practice. First, the rule gets determinate content in part from the context of practical deliberation, the network of reason seeking, reason giving, and reason using, in

23. Id. at 116 .

24. Id. at 255-56. 
which the rule is seen as a reason for action and conduct is seen as reasonable or justified (or inadequate, or failing) in its terms. In this way, the rule fits into the network of reasons engaged by the practice. Second, the content of the rule is also determined in part by the deeds already engaged in in its name (that is, within the scope of its reason giving), as judged by others who can appreciate the rule and the reason for action it offers. In this way, the rule fits into the practice's network of accountability. Without accountability to others for adhering to one's commitment, it will not be possible for an agent (from the inside, as it were) to distinguish between complying with one's rule and seeming, to one, to do so. It will not be possible to distinguish between failing to follow the rule and following a different rule. And if that distinction is not available, then it would not be possible for an agent actually to fail to follow the rule, and a rule that one cannot in principle fail to follow is not a normative rule. So, there is no way to determine the content of a rule without reference to both the deeds and the deliberative reasoning characteristic of the practice. The content of the attitudes of actors is the content determined by their participation in a deliberative normative practice.

The inseparability of concrete deeds and deliberation is evident if we attend to the natural habitat of custom. Customary rules are rules of a particular community that govern, but also emerge from, the interactions of its members. ${ }^{25}$ In this context, members of the community not only act in the presence of other members, but their conduct and deliberations are necessarily oriented toward the actions and deliberations of others. As Professor Lon Fuller pointed out, customs are not matters of simple imitation, like hikers following the path blazed by the lone pathfinder. ${ }^{26}$ Professor Fuller seems to have in mind the idea that customs emerge in contexts of social interaction in which the practical significance and force of a pattern is a function of its ability to focus the deliberation and choice of people who are oriented to each other because they are dependent on each other. For this purpose, the pattern in action must be public, "the same message in the common situation," as Professor Thomas Schelling put it. ${ }^{27}$ The message is in the deed. Any one person's grasp is adequate to its

25. For a classic discussion of this notion, see Lon L. Fuller, Human Interaction and the Law, 14 AM. J. JURIS. 1 (1969). For a discussion of Professor Fuller's account of customary rules and their importance for understanding law, see Gerald J. Postema, Implicit Law, 13 LAW \& PHIL. 361 (1994).

26. Fuller, supra note 25, at 4.

27. Thomas C. Schelling, The Strategy of Conflict 54 (1960). 
purpose-it names the deed and brings its hoped-for results-only to the extent that it meshes successfully with the grasp of others in the community with whom the agent interacts. Deed and message, behavior and practical uptake are inextricable.

There is one further problem with the proposal to fix the rule of a custom by looking to convergence of the contents of participants' attitudes. It is not uncommon that there is not anything like the same rule that every participant, or even a goodly number of participants, have in mind. As Professor Ronald Dworkin observed long ago, participants in a common practice often have quite different views about the rules of their practice. Disagreements can arise among participants regarding these rules, and on matters in dispute, the rules "in the minds" of the participants diverge. But, then, on the convergent-attitudes view under consideration, we must conclude from this that where there is disagreement, there is no rule..$^{28}$ And this is surely an unfortunate consequence of the additive conception. We are committed by the additive conception to regard disputes over customary rules as impossible, but customary rules, especially customary legal rules, are not like that; indeed, if we are to believe Dio Chrysostom, customs typically invite critical scrutiny and, as one might expect, dispute over that criticism.

\section{INTEGRATION, Not AdDition: A NORMATIVE PRACTICE ANALYSIS OF CUSTOM}

The defects of the additive conception lead us to think of Professor Hart's "internal point of view" not as something interior to an agent, but rather as the point of view from inside a practice. ${ }^{29} \mathrm{We}$ should focus on the activity, not the attitude; we should not seek to identify some "extra ingredient," which, when added to behavior, yields customary legal norms, as Professor Bederman urged, ${ }^{30}$ but rather to articulate the distinctive activity of those who participate in the practice and to account for its legal-normative character. We should ask not what we must add to usus, but rather what usus,

28. Ronald DWORKIN, TAKING RightS SERIOUSLY 46-80 (1977).

29. This point may have been what Professor Hart had in mind. Gerald J. PostemA, Legal Philosophy IN THE Twentieth Century: A COMMON LAW WORLD 294-97 (2011) (stating that some "understand[] Hart's 'distinctive normative attitude' as internal to the social practice, rather than to any person"). The phrase "distinctive normative attitude" is Hart's own. HART, supra note 22, at 255.

30. BEDERMAN, supra note 9 , at ix, 4 . 
understood as deed rather than bare behavior, comes to, how it is taken up, how it informs the thinking and choices of participants. In particular, we must consider the role it plays in their ordinary practical reasoning. The relevant, analysis-shaping metaphor is integration rather than addition.

The inquiry into the legal status of a candidate custom is not a strictly empirical matter; rather, it is in an important respect normative. As observers, we must look not simply at what participants do, but at what they do competently. This observation requires that we grasp the standards of competent performance implicit in their practice, which in turn involves some degree of competency in the practice. Moreover, because custom that is likely to be eligible for legal status is a public rule, the deliberation in which it is embedded is never a private matter, but rather involves deliberation as a common, public practice. As a result, the relationship between an individual member's participation and the practice of the group will be complex. As participants would put it, our customs are a matter of what we do, not what I might do for my own part only; but, of course, what we do comprises and is composed of what each does when doing it as part of the group practicing the custom. Thus, custom is never reducible to what each participant does or to what each says, or thinks, or believes about what each does.

My proposal, then, is to begin our inquiry into custom and its potential significance as law by looking at the role of a candidate practiced rule - a rule that accords to a deed some social significance in the practical deliberation of parties who competently use it, where that deliberation is itself part of a common activity of competent use. I begin this inquiry some distance from customary law with a characterization of customs in general, or at least of a large and important domain of phenomena that we typically call "customs," and then I consider how further to refine and specify this characterization to fit and account for legally relevant custom. But, before we proceed, a word about method is needed.

\section{A. Custom's Complexity}

The phenomena evoked since ancient times by the word "custom" and its analogues in other languages (ethos, usus, consuetudo, coutume, coustume, and the like) are very diverse. They range from mere habit (of thought or action) to conventions explicitly adopted for specific purposes; from narrow, single-purpose personal policies to broad culture-constituting traditions; from those whose 
origins are lost in the mists of the past to those newly emerging or newly minted. We might imagine these spectra arranged as intersecting axes in multidimensional space.

We could add other axes. For example, we could imagine a depth axis running from customs that are in the foreground of our attention, visible, immediately accessible, and relatively easy to make explicit, to those that lie deep in the background of our experience, implicit, largely transparent to our consciousness, bred in the bone, and defining horizons of thought or opportunities for action rather than directing them. ${ }^{31}$ We might add a life-cycle axis that runs from customs in gestation, emerging but not yet fully formed, through mature and stable customs, to those that have died, some of which remain in routines of thought or conduct, although they have lost their original point or meaning and have acquired no other revitalizing meaning. This axis would record the fact that customs often undergo career changes in midlife-having been born for one sort of purpose or problem, customs can take on new and different tasks over their life spans. We could also add an engagement axis that displays the nature and depth of engagement of participants ranging from full-fledged, committed engagement of self-identified participants to those at different points on the periphery: conformists, who are intensely interested but still on the outside; the alienated, who while on the outside nevertheless track the conduct of engaged participants and modify their own conduct accordingly; and the indifferent, who can afford to ignore the common rules of others. Customs can also vary along a discursivity axis from the entirely nondiscursive to the fully discursive (reason giving and logic governed) and explicitly discursive (that is, publicly argumentative). On the nondiscursive end we find familiar technical arts-plumbing, for example or, better maybe, jazz improvisation in a small ensemble ${ }^{32}$ - whereas forensic practices might sit on the other end. I may have overlooked yet other dimensions, but we can conclude this unsystematic survey with a moral-value axis ranging from the trivial to the morally compelling.

31. Some of these examples may also be embedded in the material world, available to us only through the objects and tools we use, consume, or display. The importance and richness of custom and culture embedded in material objects is wonderfully manifested in NEIL MACGREGOR, THE History OF THE WORLD IN 100 OBJECTS (2011).

32. See Gerald J. Postema, Salience Reasoning, 27 TOPOI 41, 47-49 (2008) ("Jazz ensemble playing relies essentially upon—and so, in its unique way, illustrates-common practical thinking."). 
In view of the complexity of this multidimensional space it is not surprising that analyses of custom differ in fundamental ways, because it is likely that they take root at different points in this space. It would be inadvisable to attempt to offer an analysis of custom that is safe from counterexamples and that purports to capture all these phenomena - or all instances of what a theorist might claim is custom "properly so-called." A more promising strategy might mimic the one that Professor David Lewis seems to have adopted for his influential analysis of conventions. ${ }^{33}$

Rather than offering a definition of conventions, a Lewisinspired approach would identify a plausible core set of social-rule phenomena and offer a philosophical explanation of how such rules function. It would then locate them in their natural habitat, for example, the practical reasoning of individual, rational agents engaged in social interactions characterized by the need for cooperation. With an account constructed for this group of phenomena in hand, we could explain other convention-like phenomena, which may not share all the features salient in the core cases, by seeing them as moving out along one or more of the axes mentioned above. Thus, for example, customs that do not seem to be immediately concerned with social coordination or cooperation may nevertheless have an important cooperative dimension that could explain why the concerns at the heart of the convention took the shape of social rules. Likewise, some conventions that seem entirely indifferent to social cooperation might be explained as, in one respect or another, "downstream" from the core cases, perhaps as vestigial conventions. Of course, such explanations are not guaranteed to satisfy, but one useful measure of success of a general philosophical account of custom is how well it can illuminate both the core cases it selects for analysis and at least some (perhaps especially puzzling) cases that, on its principle of selection, stand somewhere on the periphery.

The success of this model of explanation depends in part on the choice of core instances. This choice of instances is rarely uncontroversial, of course. But for some purposes we might agree on

33. David K. Lewis, Convention: A Philosophical Study (1969). For an extended discussion of the role Professor Lewis's analysis of conventions has played in legal philosophy in the last several decades, see PostemA, supra note 29, at 488-95. But cf. ANDREI MARMOR, SOCIAL CONVENTIONS (2009) (taking a definitional approach to conventions). For a discussion of Professor Andrei Marmor's definition of conventions, see POSTEMA, supra note 29, at 51933. 
the main constituents of the core, especially if we can agree on the purpose of the inquiry and on the kind of questions or puzzles the philosophical account is meant to address. I propose to follow this Lewis-inspired approach (although not his analysis of conventions).

The core for our purposes is roughly selected by the ultimate objective of our inquiry: explanation of law-determining custom. For this purpose, it is useful to start with phenomena having the following properties. I expect wide agreement on this list. The customs in view are: practical-pertaining to action rather than thought (for example, rules of the road rather than rules for our judgments of causation as David Hume understood them); normative-purporting to direct action (for example, modes of promise making and promise keeping rather than the predictable donning of a jacket when entering a cold meat locker); social-not only acting as rules for members of some community and evident in their conduct, but also acting recognizably as rules of the community, and not merely accidentally overlapping rules that individuals adopt just for their own part; implicit (or perhaps I should say relatively inexplicit)—not the product of explicit design but rather emerging from and finding expression in conduct. Although customs may be made explicit-that is, articulated-they do not come into existence and retain their normative status through such articulation. Finally, they are participant engaged-practiced by individual, rational agents who regard themselves as self-identified, fully engaged participants amongst other members of a practiceengaged community - and embedded in a normative practice - that is, the content of the rules is determined in the characteristic, competent performance of a normative practice. With this rough selection in hand, we can explore other features of customs so selected.

Building on earlier work, I propose to understand law-relevant custom as a certain kind of discursive normative practice. ${ }^{34} \mathrm{I}$ will introduce and elaborate two key concepts-the concept of a normative practice and the concept of a discursive practice-and situate them in what I shall argue is the natural habitat of custom: thickly interdependent social interaction. I begin with the concepts of normative practice and social interaction, drawing out salient features of customs so characterized. I will then identify a subclass of such

34. See Postema, supra note 21, at 279-306. My notion of a normative practice is based on the notion introduced and elaborated in detail in Professor Robert Brandom's discussion in Robert B. BRANDOM, MAKING IT EXPLicit (1994), and RoBERT B. BRANDOM, ARTICULATING REASONS (2000). 
customs, those that are distinctively discursive and some salient features of them, which I will argue make them law-relevant, by which I mean that these features make it appropriate for us to regard them as customary law.

\section{B. Custom as a Normative Practice}

Customs are a kind of normative practice. I explain in this Section what it is for a practice to be a normative practice, or what the characteristic mode of activity of participants in such a practice is. The explanation offered is formal rather than substantive. Practices, just insofar as they are normative, are in the business, inter alia, of offering participants normative guidance, providing them standards for their performances and reasons for their actions. But this formal account is not meant to demonstrate what gives any particular normative practice, let alone all such practices, the normative force they claim. It invites such an account as an important and expected supplement. It may also fix some of the parameters of such an account, making certain accounts and the principles or values around which they are constructed more attractive than others, but it does not offer any specific account or provide resources to adjudicate among eligible rivals. A substantive account of the normative force of a normative practice must take into account the background aims of the practice (and other moral values or principles implicated or compromised by the practice), or of those who participate in it, and the social and material context in which the practice is located.$^{35}$ The task here is only to provide a formal account of a practice's normativity. ${ }^{36}$

Customs are norms that are embedded in and emerge from conduct constituting normative practices. They are regularities of conduct that differ from other observable regularities not in the beliefs or attitudes of those who engage in it, as the additive

35. In "Custom in International Law: A Normative Practice Account," Postema, supra note 21 , at 295-300, I utilize this scheme to argue for the normative force of customary international law.

36. This distinction of tasks is rarely respected in theoretical discussions of custom. The brief sketch of custom offered by Dio Chrysostom ignores it. As part of a formal account, he quite reasonably identifies a voluntary element in custom and suggests that customs involve consensus, or agreement in some practice. But there is a shift of theoretical task to say in the same breath that the normative force of custom rests on consent. This claim is surely not guaranteed by the claims about the voluntariness of customary practice nor its manifest consensus. We do not get an argument for the normative force of custom for free. 
conception suggests, but rather in the mode of their participation in the activities. Following custom involves competent performances and judgments. Those who participate in a custom's practice undertake commitments (a) to judge certain performances as appropriate or correct and others as mistaken; (b) to act when the occasion arises in accord with these judgments; (c) to challenge conduct that falls short of these judgments; and (d) to recognize appeals to the judgments as vindications of their actions or valid criticisms of them. Such commitments are not reducible to the subjective states-beliefs, attitudes, or desires-of participants, because they are essentially normative and intersubjective. They are normative because to make a commitment of this sort is to take responsibility for one's actions and judgments and to recognize the authority of others to hold one to this responsibility, to assess one's actions and judgments in light of this assumption of responsibility. The language of commitment is the language of entitlements and responsibilities, rather than of attitudes; it is the language of what one may properly be held to, rather than language of what one holds or believes. Moreover, commitments are intersubjective: they establish or presuppose a normative relation among participants in the practice, a kind of reciprocally recognized standing or status.

Customs of the sort we have in view are normative practices planted in the soil of human social interaction (as Professor Mendelson recognized). Among the first to appreciate the importance of social interaction for customs was Hume, ${ }^{37}$ but it was Professor Fuller who introduced the idea to American jurisprudence. ${ }^{38}$ Since the 1970 s, game-theoretic accounts of social rules and conventions, that of Professor Lewis most prominently, have developed increasingly sophisticated models for Professor Fuller's suggestive ideas, but the precision and sophistication of these models come at a price. Because of their initial assumptions about the private nature of rationality, it is difficult to account for the socialthat is, intersubjective or public - and the normative character of customs. ${ }^{39}$ Moreover, because social rules on these accounts are said

37. See David Hume, A Treatise of Human Nature 311-30 (David Fate Norton \& Mary J. Norton eds., 2000) (1739-1740).

38. See Fuller, supra note 25, at 1 ("Customary law . . . has found direct expression in the conduct of men toward one another.").

39. At best, they explain how stable, convergent personal strategies might arise, but these strategies fall short of public norms. For similar problems facing Professor Hayek's otherwise fascinating account of social rules, see Gerald J. Postema, Nature as First Custom: Hayek on the 
to emerge as solutions to cooperation problems, the accounts seem to be limited to contexts of social interaction that pose cooperation problems. Yet, it would be a mistake to abandon the Hume-Fuller insight that customs presuppose and address human beings engaged in thickly interdependent social interaction. For it provides us with a ready and illuminating explanation of the necessary intersubjectivity of these rules and it leaves open the possibility of integrating the essentially discursive character of law-relevant customs into this more general account of custom.

Customs, Professor Fuller announces at the opening of his essay, find their "direct expression in the conduct of men toward one another." ${ }^{40}$ That is, customs are reciprocally oriented conduct. Customs are expressed in socially meaningful conduct and they acquire their meaning in the context of interaction. Customary conduct in its mature manifestations is decidedly not habitual behavior, unmindful of the social environment into which it is projected, but rather it is the conduct of agents aware of their environment. Like a move in a game or a dance step, it is an appropriate response to or anticipation of the conduct of others. ${ }^{41}$ Interaction of the kind that Fuller had in mind is interdependent action, and for that reason, agents engaged in social interaction are also deliberatively interdependent. The interactive environment to which parties respond consists of other parties responding to their environment, which in turn involves the responses (actual or anticipated) of the first. Caught in the net of interactions, one must know not only what others have done, but also how they understand what they have done, what they expect one to do, and so how they expect one to understand what one has done and what they have done. Social interaction is characterized by interconnected conduct and interlocked expectations. An agent acquires a grasp of what her own action might mean and what its practical upshot might be by understanding it in the context of this network of "intermeshing anticipations," from which the agents can "gauge the general scope of the repertory from which responses to their actions will be drawn." ${ }^{42}$

Evolution of Social Rules, in RESEARCH HANDBOOK ON AUSTRIAN LAW AND ECONOMICS (Peter J. Boettke \& Todd J. Zywicki eds., forthcoming 2012).

40. Fuller, supra note 25, at 1 (emphasis added).

41. Mendelson recognizes this interactive element in his account of custom in international law. Mendelson, supra note 14, at 189-91.

42. Fuller, supra note 25 , at 2. 
Customs are relatively stable points or nodes in the network of expectations. The meaning or content of customs typically arises from salient patterns of past actions in the group, but these patterns are not accessible apart from the network of anticipations or of the choices and deliberations of others in which each shares. ${ }^{43}$ Thus, custom following is never a matter of rote repetition of one's past behavior, disengaged imitation of observed behavior of others, or simple application of a preconceived representation or rule. Rather, it involves the agent grasping the significance of some pattern and recognizing its application in the given circumstances of the conduct, against the background of intermeshing anticipations and understandings of others. The fact that we learn to grasp patterns and recognize how to follow them quickly and effortlessly in much of our social interaction should not blind us to the complex dimensions of custom-following activity. ${ }^{44}$

Customs understood as normative practices emerging from the soil of social interaction have four important properties we can isolate: they are public, temporal, concrete, and internally interconnected. First, customs are public and the deeds that purport to follow them are uttered conduct. Not only are individual actions offered in public space, but also the significance and standing, the point of engaging in them, depends in part at least on their public recognition or anticipation. Customs lend public significance to actions undertaken in contexts of social interaction and thereby enable them to achieve individually and collectively sought outcomes.

Second, customs are temporal. They are mortal; they come into existence at or over some discrete period of time and die or petrify at some later time. Their vitality is a function of the ability of agents

43. In "Salience Reasoning," Postema, supra note 32, at 36, I argue that deliberative reasoning in this context is a form of common reasoning.

44. Of course, it is possible that some behavior we are inclined to treat as custom following does not have this character at all, at least to the agents involved. For example, the complex interactive dimension of the conduct may be entirely invisible to the agent involved because the nodes in the network are very stable and the practice of them is deep set in an agent's behavioral routine. In this case, the custom itself may rise to visibility only when something goes wrong, and even then it may be difficult for the agent to articulate what went wrong. But also it is possible that the behavioral routine has been so deeply bred in the bone that it persists even after all calls for it to help navigate social interactions are silenced. Some customs, as noted above, die and dissolve, but others petrify, remaining in an agent's behavioral repertory long after they have any point. The facts surveyed in this footnote do not challenge my main thesis that mature and vital customs take their life in and from a network of thickly interdependent social interaction. 
caught in webs of social interaction to use them to navigate successfully their common world. But there is more to the temporal dimension of customs than their life spans. Customs are often thought to be necessarily ancient, immemorial, or at least of some significantly long duration. Dio Chrysostom maintained that customs are invented "by life and time." 45 Thus, the talk of instant custom strikes some as paradoxical or even nonsensical. In many legal contexts, however, the requirement of duration seems motivated largely by evidentiary concerns. It is thought necessary to require proof that a custom has been in effect in a community for some years-for Blackstone's English common law, from "immemorial usage," that is, since the beginning of Richard I's reign in $1189^{46}$-in order to avoid formally acknowledging and enforcing practices that are ephemeral or the product of narrow interests or to avoid confusing custom with wishful thinking or cheap talk. But these concerns treat the temporal dimension of custom as a useful proxy for other qualities deemed important. There is nothing fundamentally paradoxical about "instant custom." Stable points in a network of expectations often form over time, but this is not essential to their nature. What is essential is their place in the network, however it is acquired.

Yet, custom typically does have a deeper temporal significance, not because venerable custom is reliably wise or good, but rather because custom works by structuring time in some domain of social life. Customs structure or anchor time in the way meter anchors time in music. Professor Jeremy Begbie writes, "Temporality in music is principally manifest through rhythm, more precisely, through rhythm interacting with metre. Metre is a configuration of beats permeating a piece of music." ${ }^{, 47}$ The wave-like ebb and flow of meter makes possible the vastly varying and engaging patterns of rhythm. The meter that we feel anchors, and in that way makes possible, the rhythm we hear; the significance of that rhythm is necessarily extended over time and is inconceivable otherwise. ${ }^{48}$ Likewise, custom enables meaningful regularities and variations in social interaction and this meaningfulness could not be achieved except over time. To be mindful of custom in a domain of social life is to be mindful of

45. CHRYsostom, supra note 2, at 253.

46. 1 William Blackstone, COMMENTARIES *78. For a discussion of the duration needed to establish a practice as a matter of customary international law, see LEPARD, supra note 12 , at $35-36,224-28$.

47. JeRemy S. Begbie, Theology, Music AND Time 39 (2000) (footnote omitted).

48. Id. at $39-44$. 
time in that domain, mindful of the public significance of conduct over time for members of the custom community.

Third, customs are concretely practical. By this, I have in mind the fact that customs are not merely prescriptions for action, but are modes of conduct that arise from and are embedded in deeds in a complex way. Learning to make one's way within a normative practice involves mastering a discipline-a discipline of grasping the custom-relevant significance of actions in their concrete circumstances (Professor Llewellyn called this "situation sense") and of judging how to apply rules to those circumstances (Kant called this "Mutterwitz"). Moreover, because customary rules arise from practice, they are answerable to the deeds that make up the practice. The activity of the practice, not any articulated account of it, nor theoretical reconstruction of it, is on its own authoritative. The practice is the commons from which all participants draw and to which they all contribute. What is decisive for parties is not what any participant thinks, or a majority or even all participants at a time think, about what is or ought to be done, but what the participants are actually doing. That is a matter to be construed by any and all. What anchors participants' disputes about the nature and force of what they are doing is the doing and not their beliefs about it. This anchoring is a direct implication of the crucial fact that what any of them say or think is subject to standards of correctness implicit in the practice, standards anyone familiar with the practice can deploy to assess what is said or thought. It is entailed by the fact that the recognition of standing to hold participants to their commitments is mutual and reciprocal. No one, not even the entire community, has unchallengeable, final say on what the norms of the practice are. Thus, disputes about what we are doing (as participants put it) are not in themselves threats to the practice, neither are they evidence that the practice is unraveling, but rather they can be expected, especially when what we are doing is important and the stakes are high. It follows that no proposal for an understanding of what we are doing or required to do in some range of instances of the practice is ruled out on the ground that it is novel or not widely accepted. The credibility of the proposed understanding will depend on the strength of the case that can be made for its being integral to the practice as a whole. ${ }^{49}$

49. The points of this paragraph are, of course, familiar to readers of RONALD DWORKIN, LAW'S EMPIRE (1986), although the dynamics of custom were far from his mind. Professor Dworkin tended to dismiss custom as "runic traditionalism." Id. at 89. 
Finally, customs are typically internally interconnected; they tend to hunt in packs. Professor Ekkehart Schlicht gives a simple, homely example. The old-fashioned polite greeting of tipping one's hat depends on the custom of wearing of hats. ${ }^{50}$ More complexly interwoven customs structure the high-stakes interactions among drivers on the highways and between drivers and pedestrians on urban streets. An explanation of this interconnectedness is ready to hand. Customs, on the useful Fullerian picture we considered earlier, are stable nodes in a network of "intermeshing anticipations," in a repertoire of actions, responses, countermoves, and corrections. ${ }^{51}$ The code shaping this scheme could not merely be an aggregate of discrete and unrelated rules. The various component rules or nodes would surely be sensitive to the weight and pull of other nodes when one of them seems implicated in some given circumstances. Discrete and isolated customs are not inconceivable, but they are likely to be rare largely because our occasions for social interaction from which customs arise and to which they are addressed are rarely discrete and isolated.

\section{Discursive Normative Practices}

This account of custom as interaction-embedded normative practices could apply equally to commercial practices, to rules of international diplomacy, and to jazz improvisation in a small ensemble. Not only is there nothing necessarily linguistic about these practices-that is, nothing requiring articulation in language-but also this account does not recognize that some interaction-embedded normative practices are discursive, not just accidentally or in part, but essentially. Parties who engage in discursive normative practices are not only in the business of using and articulating concepts, but also they offer, explore, and assess reasons and arguments. The moves and countermoves they make are moves in argument-offering claims, counterclaims, challenges, and responses, offers of warrants for action and rejections of them. The norms of a discursive normative practice get their content from the roles they play in networks of reasons and argument. Identifying and fixing the requirements of norms of a discursive practice involves exploring the reasons and arguments for and against them and the conclusions that they support and those they do not support. Thus, the discipline mastery of which is required

50. EKKEHART SCHLICHT, ON CUSTOM IN THE ECONOMY 144-45 (1998).

51. Fuller, supra note 25, at 2. 
for full participation in these custom-forming normative practices is a discipline of deliberative reasoning. Discursive practices make possible thoughtful, public adjusting of norms to changing circumstances, renegotiating on the ground, as it were, the terms of commitments within the practice. Dio Chrysostom thought critical scrutiny was typical of all custom; even if he overstated the case, he was surely correct about customs that take shape in discursive normative practices.

Discursive normative practices are thickly systematic. Customs take their content and practical force from two systems into which they are integrated: the system of intermeshing anticipations of the social interaction network and the discursive system of reasons and arguments, which we might call the "discursive network." The existence, content, proper scope, and normative force of customary norms are all functions of the place they hold in the discursive network, and their ability to guide and shape the deliberations and actions of members of the custom community depends on the members' mastery of the discipline of argument that is characteristic of the practice. Customary norms are established, and they mature, not by virtue of repetition or imitation, and not by virtue of the fact, or parties' beliefs, that they ought to be established, but rather by virtue of their integration into the discursive network. And whether or not a candidate customary norm has such a place, whether it is indeed integrated into the system, is settled neither by empirical observation of parties' behavior, nor by interrogating them to determine what they believe or even what they accept, but rather by demonstrating by argument internal to the system of that normative practice that they have such a place in it. This is an essentially normative and discursive, rather than evidential, mode of demonstration. Integration is the fundamental test; any other is parasitic on it. And, because of the intensely practical orientation of custom's normative practice, this integration is not an abstract, theoretical matter, but rather a matter of adjustment and accommodation of action and mutual expectations. Integration is an essential part of the process of custom formation, a process that is discursive, but always also public and intensely pragmatic.

It follows, then, that in discursive normative practices the distinction between deeds and words breaks down. It would be a mistake to say that conduct is unnecessary and all that is needed for 
the formation of a custom are arguments (evidence of opinio juris). ${ }^{52}$ For arguments in discursive normative practices are arguments about and drawn from deeds. And in view of the essential concreteness of customs, such arguments, which involve articulations of deeds and the rules implicit in them, are answerable to deeds. But it also is true that in discursive normative practices, words-that is, publicly articulated claims, counterclaims, and arguments about both-are among the custom-relevant deeds. Words and deeds are equally important aspects of the practice. Participants' deeds and words are constituent elements of the deliberative practice, not merely evidence of something else (for example, the mental states of participants) that constitutes the practice as the additive conception would have us believe. Through deed and word, custom-forming commitments are undertaken, recognized, affirmed, challenged, revised, and extended. In the formation of custom, deed and word work together. Through articulating claims and responses, the deed takes on custom-relevant significance. Thus, for example, in international law whether the action of a state counts as a juridical claim or an act of comity, or whether silence on the part of other potentially interested parties counts as a response to the claim, let alone as acquiescence to or protest against it, is never a function of the mental state of the agents or observers (their opinio juris or otherwise), but of their proper articulation and defense, as dictated by proprieties of the background normative practice.

\section{CUSTOMARY LAW}

At this point, one might reasonably ask what this account of custom has to do with legally significant custom or customary law. Can customs embedded in normative practices count as law? We can begin to answer this question by distinguishing two versions of the question. One version asks a generic question about the legal status of custom regimes or systems understood as large-scale discursive

52. For recent discussions by theorists who hold this view, see, for example, LEPARD, supra note 12, at 6; and Tasioulas, supra note 10, at 30; see also Michael Akehurst, Custom as a Source of International Law, 47 BRIT. Y.B. INT'L L. 1, 8 (1974-1975), which argues that it is possible for states to change undesirable customs "by repeatedly declaring that the old rule no longer exists." Critics of so-called "new" or "declaratory" international law sometimes see the decision of the International Court of Justice in the case of Military and Paramilitary Activities in and Against Nicaragua (Nicar. v. U.S.), 1986 I.C.J. 14, 101-02 (June 27), as accepting this view, see Frederic L. Kirgis, Jr., Appraisals of the ICJ's Decision: Nicaragua v. United States (Merits), 81 AM. J. INT'L L. 146, 147 (1987). 
normative practices; a second version asks a more specific question about the legal status of some candidate customary norm. The first asks, generically, what makes custom regimes so described law, while the latter asks what makes this or that custom a law. I consider the generic version first.

\section{A. What Makes Custom Law? The Generic Question}

We can take the generic question in two ways: we can ask what makes custom regimes described in this way law ("law properly socalled," some might say) or we can ask of some customary legal regime whether it is or approximates a large-scale discursive normative practice. Taken the first way, we might ask whether, for example, the medieval transnational commercial system (the so-called lex mercatoria), assuming it is adequately described by the normative practice account, was a system of customary $l a w .{ }^{53}$ To make this claim raises large questions of general jurisprudence, which I will not address here. But a more limited response is possible. We can point out, for example, that custom regimes characterized by the normative practice account are remarkably law-like; that there are strong similarities between them and municipal legal systems, despite undeniable dissimilarities. Both are public, discursive, and argumentative. Although the formal institutional features of municipal law may not be found to the same degree in customary regimes, there are still significant analogies of function and form to warrant regarding them, for many purposes, as legal or quasi-legal systems. Ultimately, however, this way of formulating the generic question is not very interesting. A more interesting question is whether the discursive normative practice account fits widely accepted examples of customary law regimes, for example, customary international law. The answer to this question is a clear and definite yes.

53. A lively debate has arisen over the nature of medieval lex mercatoria. Professor Leon E. Trakman makes a strong case for the evolved, strictly private, customary nature of lex mercatoria. See generally LEON E. TRAKMAN, THE LAW MERCHANT: THE EvOlution of Commercial Law (1983); Leon E. Trakman, From the Medieval Law Merchant to E-Merchant Law, 53 U. TORONTO L.J. 265 (2003). Professor Emily Kadens offers a powerful challenge to this thesis, arguing that the most important parts of medieval commercial law had their roots in contract and legislation and that public fora were as likely to be used to solve disputes as private ones. See Emily Kadens, Order Within Law, Variety Within Custom: The Character of the Medieval Merchant Law, 5 CHI. J. INT'L L. 39, 42 (2004); Emily Kadens, The Myth of the Customary Law Merchant, 90 TEX. L. REV. 1153, 1160 (2012). 
The domain of international relations is understood by some observers to be a close approximation of a Hobbesian state of nature, dominated by actors (states) motivated solely by rational self-interest. Such actors are thought to have no capacity to grasp norms, (other than norms of rational, expected-utility maximization, of course) let alone to be motivated by them. Thus, on this view, international law as a normative enterprise is a myth. ${ }^{54}$ The alleged myth reflects actual phenomena-a complex interactive, discursive, and norm-governed process-but this process is causally inefficacious and so is explanatorily vacuous.

We need not settle here the long-running debate between the realist, rational-actor theory and its institutional, norm-recognizing rivals, because the issue addressed by the normative practice account of custom is not one of causal explanation but rather of socialpractice interpretation. The question for us is whether that proposed interpretation scheme is adequate to the phenomena of transnational activity thought to be structured by customary international law. Those phenomena are not in fact challenged by realist skepticism; on the contrary, realist skepticism presupposes the phenomena and then denies their causal efficacy. It is these phenomena we need to examine in order to judge the relevance and usefulness of the normative practice account of custom defended in this Section.

Students of international relations who recognize some role for international norms, whether treaty-based or custom-based, and so recognize international law in some form, describe the domain as one which, at its center, is a complexly interactive, iterative, and essentially discursive process. "[A] discursive process of explanation, justification, and persuasion is a central attribute of international affairs," write Professors Abram and Antonia Chayes. ${ }^{55}$ They suggest that, as a matter of practical necessity, caused by deep and broad interdependence and the strong need for an effective international system, international actors are forced to give reasons for their past or proposed actions, to characterize their deeds, and to explain and

54. See, e.g., JACK L. GOLDSMith \& ERIC A. POSNER, The Limits OF INTERNATIONAL LAW 13 (2005).

55. Abram Chayes \& Antonia Handler Chayes, The New Sovereignty 127 (1995); see also THOMAS M. FRANCK, FAIRNESS IN INTERNATIONAL LAW AND INSTITUTIONS 14 (1995) (describing international law as a "process of discourse, reasoning, and negotiation" (emphasis omitted)); id. at 477 ("[M] uch of the attempt at interaction [in the transnational domain] is discursive: an interlocutory process of exhortation, expiation, explanation, and exposition."). 
justify them to the relevant transnational publics. These proffered interpretations and justifications, in turn, are reviewed, evaluated, reinterpreted, accepted, or challenged by other parties, which invites further argumentative response from the original actor and others. ${ }^{56}$ This process involves many transnational actors, including heads of state, diplomats, legislators, and other state officials; international, regional, and domestic courts; ad hoc tribunals; transnational institutions, such as the United Nations Security Council; nongovernmental organizations and a host of other less formal or institutionalized discourse participants. ${ }^{57}$ This context of discourse is more diffuse and decentralized than that of municipal legal systems, but it has a broadly similar discursive structure. "[I]n international relations, where authoritative determinations analogous to umpires' rulings are the exception, the parties themselves must interpret each others' moves and constantly renegotiate the reality in which they operate," Professor Friedrich Kratochwil observes. ${ }^{58}$ Claims are advanced and interpretations and defenses of actions are offered; exchanges of interpretations are made with other parties; counterclaims or challenges are advanced; arguments are offered, reviewed, assessed, and answered. "In the international system, which does not have the benefit of much judicial assistance, the norms are interpreted, elaborated, shaped, reformulated, and applied" by a variety of parties in "the course of debate about the justification for contested action. The discourse is not confined to the meaning of the norm, but extends to the acceptable grounds or excuse for nonperformance., ${ }^{60}$

The customary law process in particular, Professor Mendelson observed, "is one of continuous claim and response," claiming and responding (and responding to the response, etc.) are carried on in an articulated, discursive mode, through offering interpretations, reasons, and arguments drawing on the regime of customary law. It is "[o]ut of this constant process of claim and response [that] rules emerge, are strengthened, or are superseded." ${ }^{, 2}$

56. CHAYES \& CHAYES, supra note 55, at 25-26, 28, 118-23.

57. Harold Hongju Koh, Why Do Nations Obey International Law?, 106 YALE L.J. 2599, 2640 (1996).

58. Friedrich V. KRATOCHWIL, Rules, NORMS, AND DECISIONS 102 (1989).

59. CHAYES \& CHAYES, supra note 55, at 122.

60. Id.

61. Mendelson, supra note 14, at 189-91.

62. Id. at 190 . 
The normative practice account of custom fits comfortably the phenomena of international customary law described by these observers.

\section{B. What Makes a Custom a Law? The Specific Question}

We distinguished a second question about the legal status of custom as characterized in this Essay. We can ask what makes this or that alleged customary rule a law, that is, what makes it legally significant or binding. This is the form of the question in which theorists of municipal and international law are typically more interested. The account of customary norms articulated above provides a sophisticated answer to this question. Note, first, that on this account, whether any alleged rule is binding or practically significant as a custom is settled by determining whether it has a place or role in some ongoing, practically oriented, discursive normative practice. What qualifies a norm as a normatively significant custom, we saw earlier, is its integration into a discursive, deed-based system of norms. ${ }^{63} \mathrm{We}$ also saw that whether a given norm is so integrated is a matter determined not by observation or interrogation of participants' beliefs or attitudes, but discursively, by argument. ${ }^{64}$ So, the question of whether some alleged custom is binding is always answered relative to some practice, arguing that it has a proper place in its system of norms. A fortiori, the question whether a custom is legally binding is answered not in general but relative to some particular legal system or other.

Thus, on the normative practice account, what qualifies a given custom as legally significant or binding in some legal system is whether that custom is incorporated into the larger set of norms of that legal system, or, more likely, whether it is integrated into a custom regime which in turn is incorporated into the legal system. How, then, does one know whether some activity in which states seem to engage with some regularity is governed by a binding norm of customary international law, as opposed to being a matter of comity, mere politeness, mere convergence of behavior-serving self-interest, or sheer habit? The answer is that this fact is not to be determined by exploring the beliefs or attitudes of states or their officials, but rather to look at the way the conduct is "read" in the transnational public domain. In particular, it is determined by how the agents tend to

63. See supra Part III.C.

64. See supra Part III.C. 
characterize their actions, the terms in which they seek to vindicate them, how these attempts are taken up by other participants in the practice, how the actions are affirmed, resisted, criticized, and the like. We can determine this fact, to some degree, "from the outside" by looking at the kinds of interpretations and arguments that are given for and against the act, how those arguments are related to other descriptions and arguments, and the like. The normative practice account insists, however, that ultimately the legal status of any alleged norm is determined by the place it actually has in the practice system, and that is a matter for discursive argument, not external observation (even if it is observation of the arguments of others). Claims about the legally binding status of some alleged custom are only discharged discursively, that is, by substantive argument.

This discursive account represents a fundamental challenge to the additive conception of custom's answer to the question of what makes an alleged custom legally binding because substantive reasons, not evidence from external observations (and inferences to claims about internal states), are the only currency recognized by the normative practice account. We, however, must introduce one qualification of this account of what qualifies a custom as legally binding. The qualification stems from the observation that it is a contingent matter whether custom plays any role in a given legal system and, if it does play a role, what role that is. These determinations can vary across legal systems. A legal system may give no role to custom or it may give it a role under certain more-or-less limited conditions. Thus, a legal system may impose pedigree-like conditions on the validity of customs in that system. Among such conditions might be, for example, that customs must be approved by the sovereign or recognized by the courts, or, like English common law did, according to Blackstone, it might require that customs be ancient, continued, peaceable, certain, compulsory, consistent, and reasonable. ${ }^{65}$ A legal system might even insist that for a custom to acquire legally binding status in its domain there must be proof of long consistent usus and demonstrable opinio juris on the part of those participating in the practice. Legal systems might impose such conditions in various ways-in constitutional instruments, by explicit legislation, through the development of judicial doctrine, or even through being rooted in a principle never explicitly enacted. They

65. BlaCKSTONE, supra note 46 , at *76-79. 
may do so for a variety of reasons of policy, principle, evidentiary reliability, or the like. But the conditions would be specific to the legal system in view, not general conditions on what qualifies custom for legal significance. And the content and force of such customlimiting conditions is, of course, determined by the best general theory of that system as a whole, taking all its elements into account.

These considerations make the normative practice account more complex, but they are not inconsistent with it. Indeed, they are actually required by it. For on this account whether a custom has legal significance in a given legal system is strictly a matter of its integration into the custom regime that is an integral part of that system. The arguments for such integration must take into account all relevant components of the system. Principles laying out criteria for the legal status of customs in the system may be among those components. So, to determine whether a custom has legal significance in that system one must take into account those criteria-defining principles.

The lesson to be learned from this qualification is twofold. First, perhaps we should not entirely consign the additive framework to the jurisprudential scrap heap, because it may play a role in some legal systems as a more or less convenient proxy for a more nuanced explanation of the legal status of custom in those systems. The additive conception may be among those legal doctrines and conceptions, which, although unfortunate and perhaps not entirely coherent, nevertheless do some work (and perhaps do damage) in actual legal systems. But, second, we should also recognize that the additive conception is not forced on any existing legal system. There is an alternative understanding that is one far more plausible and workable. If a legal system chooses to utilize the additive conception, it should do so aware that it is creating unnecessary trouble.

\section{CONCLUSION}

International law gives normative shape to conduct through a complex, interactive, essentially discursive process. Custom plays an essential role in this process. Custom is pervasive in social life and in law and, arguably, custom is foundational in international law. Custom takes many widely varying forms in social life. I have argued that legally relevant custom-custom that can play a significant role in law-is best understood as embedded in discursive normative practices among parties who are engaged in networks of 
deliberatively interdependent interaction. Legally relevant customs are forms of reciprocally oriented conduct that takes its meaning from a practice of offering claims and counterclaims, challenges and responses. The hallmark of such customs is not the addition of belief (opinio juris) to behavior (usus), but rather the integration of meaningful conduct into a web of reasons and arguments. A norm rooted in conduct is a norm of customary international law in virtue of its integration into the system of norms (the corpus juris) of international law, not in virtue of beliefs of actors or judges about the legal status or bindingness of the norm. The place that a norm holds in the system is established by normative argument, tracing its internal connections to other norms of the system and to conduct that complies with them. Argument, not attitude, determines legal status of a customary norm. Integration is not an ingredient added to conduct; rather, it supplies the context in which the conduct acquires its normative significance. Outside of that context it is a "deed without a name."

66. This echoes the witches' characterization of their inscrutable behavior in WILLIAM Shakespeare, Macbeth, act 4, sc. 1, line 48 (A.R. Braunmuller ed., Cambridge Univ. Press 2008). 